\title{
A Review on posture monitoring systems
}

\author{
Ferdews Tlili*, Rim Haddad*, Youssef Ouakrim ${ }^{\dagger}$, Ridha Bouallegue*, Neila Mezghani ${ }^{\dagger}$ \\ * Laboratoire Innov'Com, Ecole Suprieure des Communications de Tunis, Université de Carthage \\ Email: ferdews.tlili@ supcom.tn,rim.haddad@supcom.tn, ridha.bouallegue@ supcom.tn \\ ${ }^{\dagger}$ Laboratoire de recherche en imagerie et orthopédie, TELUQ university, Montreal, Qc, Canada \\ Email: Youssef.Ouakrim@teluq.ca, neila.mezghani@teluq.ca \\ ${ }_{\ddagger}^{\ddagger}$ Centre de recherche du CHUM, Montreal, Qc, Canada
}

\begin{abstract}
The bad sitting posture leads to many back problems for young people. Nowadays the adults and young people seat for long hours hunching over their laptops and tablets. Recent researches are focus on the study and develop systems to prevent the seated persons from spinal pain with monitoring and improve the sitting posture in real-time. In this study we analyze the specification of sitting posture monitoring systems, the information required to define the human posture, the technologies used and the systems limits. The person posture can be identified by different information provided by the sensing technologies. This research can be a reference for future study for posture monitoring systems.
\end{abstract}

Index Terms - sitting posture monitoring, inertial sensors, tilt angle, pressure sensors, weight information, flexible sensors, spine curvature information

\section{INTRODUCTION}

The young people suffer from many back problems caused by leaning for long hours to their computer, tablets and phones. A recent study shows that looking down to the phone is equivalent to placing a 60 pound weight on one's neck [1]. In fact tilting the head down to check Facebook or write a message on your smartphone leads to a stress of the spine. The continually use of the computers and smartphones without a survey to maintain straight posture causes many backs diseases such as low back pain, kyphosis and pain in the neck.

The kyphosis or roundback of the spine can occur at any age specially during adolescence. This disease is an excessive spine curve because of abnormal rounding of upper back. This spine disorder can lead to breathing problems. The severe Kyphosis, significant deformation of the spine, may need a surgical treatment. According to a medical research the majority of patient cases can cure and prevent severe Kyphosis by making exercises to improve the sitting posture and maintain a spine straight [2].

Thus many researches are triggered to implement and develop systems to help person to monitor and improve their posture. These systems are composed of three main elements. The first component collects the information to define the spine shape. The second one analyzes the collected information. The third element is a feedback system to alert the user in case of bad posture. The function of the three components are based on the collected information. For this reason the systems proposed in literature used different types of information to define the human posture according to the used technologies.

Many posture monitoring systems are based on the vision cameras [3]-[6]. These systems provide real time images to monitor the person's posture over time. The systems compare the photos of the current posture with the photos of the correct posture and send alert to the user wrong posture. A recent research proposes a sitting posture monitoring system using Kinect IR depth camera [7]. the system collects the visual data and provides alert in case of the bad posture. These systems help users to improve their posture and correct the sitting behavior. However these systems threaten the personal privacy because of use of visual information.

Recently the sensing technologies have known an evolution and spread of use in different fields specially in medical and Health care systems. The sensors are characterized by portability, low cost, ease of use and tiny size [8]. In addition these tiny devices provide a variety of information that can be useful to define the person posture. In literature many researches proposes posture monitoring systems for sitting person using the sensors that provide different information to define the spine shape. The information provided by the sensors save the human privacy.

In this work we present an overview about the sitting posture monitoring systems with focus on the information needed to define the spine shape using the sensing technologies. We classify the posture monitoring systems based on the type of information required to identify the person's posture and we analyze the technologies used and the systems architecture.

This paper consists of four sections. In section II, we describe the existing sitting posture monitoring systems and in section III, we compare the different characteristics of the sitting posture monitoring systems. Section IV, we conclude the study with the prospects for future work.

\section{Posture Monitoring Systems FOR SEATEd PERson}

In this section, we describe the existing sitting posture monitoring system. These systems are classified according to the type of information provided by the sensing technologies to define the person's posture.

\section{A. Posture monitoring systems based on Weight information}

In literature many posture monitoring systems based on the weight information are proposed [9]-[11].The weight 
information used to define the spine shape is provided by the load or pressure sensors.

Jongryun et al [9] describe a new sitting posture monitoring system. The system analyze the body weight ratio for identify the person's sitting posture. The system consists of four load cell placed into backrest and seat plate of the chair. The collected information are sent to a computer via an Arduino board in order to analyze and classify the sitting postures. This system is able to define different types of sitting posture as shown in Figure 1.

Jingyuan Cheng et al. [10] propose a posture monitoring system. The system provides the total weight, the distribution of the weight and the pressure exercised to the four legs in order to identify the posture and monitor the head and the hand motion. The pressure sensors are sticked under the chair legs.

A new research by Jullia Birsan et all [11] is based on the weight distribution information. The system is composed of eleven pressure sensors: nine sensors are placed on the pillow and two sensors are mounted on the back. The provided weight data are analyzed in order to define the spine shape.

The weight based posture monitoring systems are efficient to define the sitting posture. However these systems utilize special chair or platform to implement the sensors. These systems are not portable and used in specific environment.

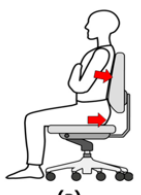

(a)

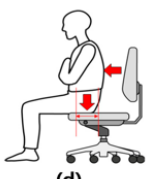

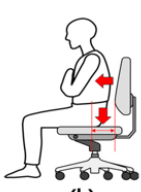

(b)

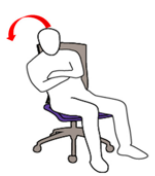

(e)
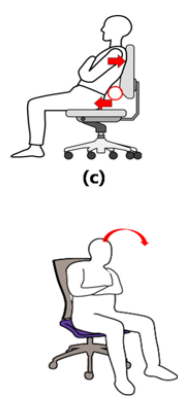

(f)
Fig. 1. Types of sitting postures : (a) upright sitting with backrest; (b) upright sitting without backrest; (c) front sitting with backrest ; (d) front sitting without backrest ; (e) left sitting ; and (f) right sitting [9].

\section{B. Posture Monitoring Systems Based on Tilt Angle informa- tion}

The tilt angle relative to the gravity and linear acceleration are provided by the inertial sensors. The inertial sensors are used in several fields industrial [12], medical [13] and aerospace researchers [14]. The inertial sensors are widely used because they satisfy the portability aspect. The sensors can be sticked to the person clothes.

Wai Yin Wong and Man Sang Wong [15] propose a sitting posture monitoring system. The system provides the tilt angles of trunk, thoracic and lumbor regions. The system consists of Inertial sensors: one 3D accelerometer and three gyroscopes. The system tracks the posture curvature during the trunk movement.
Q. Wang et all [16] present a posture monitoring system for patient. The system is a Smart Rehabilitation Garment (SRG). The inertial sensors are mounted on the patient clothes. The thoracic angle of slouching position is defined by the inertial units placed on T4 and T5 vertebrae as shown in Figure 2. The compensatory movement is the average of the thoracic angle according to the vertical plane. The calculated angle information is sent to Arduino processor via wireless Bluetooth communication. In case of hunching position and wrong patient posture a feedback system consists of vibration motor and smartphone's visual and audio signal to alert the patient and enable him to improve his sitting posture.

A new posture monitoring system offered to sitting workers proposed by Maheswaran Shanmugam et all [17]. The system defines the bend posture angle by converting the acceleration angle and gyroscope acceleration using map function. The system is equiped with gyroscope and accelometer placed at the lower back or at the shirt pocket, Bluetooth module to ensure the communication between the different components of system, android application running on smartphone to record and analyze the sensor information and a warning system composed of led notifications and a vibrator unit. The system classifies the identified posture to bad posture or good posture according to the angle information.

The systems based on the tilt angle of posture are the most efficiency posture monitoring systems. These systems are able to monitor the spine motion in real time and give a real view of the spine shape. However, the tilt angle accuracy is depending on the the sensors position. In fact, the sensors must be glued to the person body.
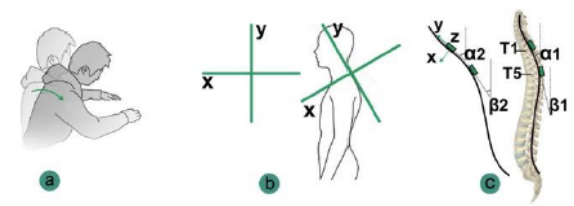

Fig. 2. Angle Calculations. (a) Compensation Movement. (b) Zero Degree Calibration. (c) Calibration Model [16].

\section{Posture monitoring systems based on Spine curvature in- formation}

The bad posture can be detected based on the spine curvature information. This information is useful to define the spine shape over the time. Many sensing technologies are able to provide this information to posture monitoring system in order to elaborate decision about the person posture. In literature the main technologies used are the flexible sensors [20], the inductor sensors [21] and the optical fiber sensors [22].

The flexible sensors define the spine curvature due to the polyvinylidene fluoride which is a flexible piezoelectric material. These materials are sensitive to extension without changing properties [18]. The resistance changing of the flexible sensor provide a great information to identify the spine curvature. Moreover this kind of sensors are characterized by a long duration of use and low cost [19]. A posture monitoring 
system using flex sensors is proposed by Manju Gopinath and Angeline Kirubha [20]. The system is composed of a flex sensor and a load cell. The flex sensor is placed on the mid-thoracic to define the person posture. The load cell is composed of weight sensor in order to define the spine stress. The flex sensors depends to the sensor position to detect the wrong posture [20]. In fact the sensor glued to the lumbar or the lower thoracic is never able to identify the wrong posture. Moreover the small spine curvature and bend angle are not detectable by the flex sensors [19].

Emilio Sardini et all [21] propose a posture monitoring system based on the spine curvature information defined by the variation of inductance detected by inductor sensors. The body deformation leads the lenthening and straightening of the geometric of the inductor sensor.In fact the impedance measurements and the elongation variation are useful to define the posture curvature. The proposed system in [21] consists of T-shirt, a readout unit, a treatment unit PC and feedback system. The T-shirt is equipped with a inductor sensor stitched on the back and front as shown in Figure 3. A readout unit collects the inductance variations and sends them to the PC. The PC analyzes the information and classify them according to the recorded posture information. Two vibrofeedback sensors are the feedback system to alert in case of wrong posture detection. This system is limited to define the sagittal spine curvature. The left and right bend of posture is never identified by the inductor sensors.

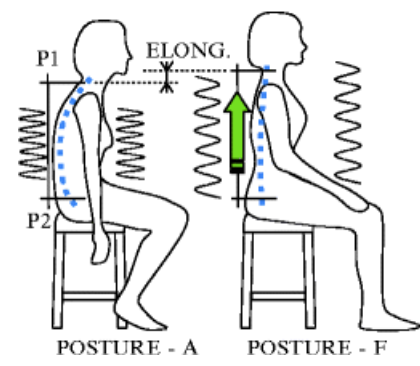

Fig. 3. Principle of a posture monitoring systems inductor-based [21].

The spine curvature can be defined using the optical fiber sensors. The amount of voltage detected between the lignt source and light sensor are the main information to identify the spine shape. Dunne et al [22] describe a sitting posture monitoring system using a fiber optical sensors. The system is composed of two optical fiber ends stuck to a garment. The communication between different system component is ensured by a serial Bluetooth unit. The collected information are treated by a computer that classify the detected information. A software interface is implemented to send warning messages in case of wrong posture. The accuracy of the collected information via the optical fiber sensor depends on the sensor position. Any change of the sensor position can damage the precision of system to define the spine curvature.

The posture monitoring systems based on the spine curvature information defined by the flexible sensors [20], the inductor sensors [21] or the optical fiber sensors [22] have a common limitation that is their sensitive to the sensor position.

\section{POSTURE MONITORING SySTEMS COMPARISON}

Recently the sitting posture monitoring systems topic is deeply studied in literature. The evolution of the sensing technologies leads to a variety of information provided by the sensors. The sensing information have been useful for the development of the posture monitoring systems. In this paper we analyze different posture monitoring systems. We classify the systems according to the information used for define the posture as shown in Table I and II below: 3 systems using weight information, 7 systems using tilt angle information and 3 systems using curvature spine information.

The possibility to identify the maximum sitting postures is the important aspect to evaluate the sitting posture monitoring systems. In fact the posture monitoring systems based on the weight information are the best sitting posture monitoring systems that detects the different types of sitting posture. In [9] the system define six different sitting postures: upright sitting with backrest, upright sitting without backrest, front sitting with backrest, front sitting without backrest, left sitting and right sitting. However the systems based on the curvature spine information are the worst one to identify the variety of posture position. The systems based on curvature spine information provided by the flexible sensors are not able to identify the small bend and curvature of the spine [19]. Moreover the posture monitoring systems using curvature spine information defined by the inductor sensors do not detect the left and right postures [21].

Although the variety of posture monitoring information the sitting posture monitoring systems defined in literature are sensitive to the sensors position. Any change of sensors position during the posture measurement leads to errors of sitting posture information. The most systems sensitive to sensors position are the systems based on the tilt angle [15][17] and the systems based on the curvature spine information [20]-[22]. However the posture monitoring systems based on the weight information are less impacted by the sensors position change because the sensors are implemented and fixed to special platform or chair.

The sitting posture monitoring systems based on weight information are efficient to define the different sitting posture. But they are static platform and not portable because the sensors are fixed to chair legs, backrest or seat plate [9] [10]. The systems based on tilt angle and curvature spine information are relatively portable while the sensors are mounted to the user clothes.

Recently some proposed posture monitoring systems define a system combine two sensing information. In [26] the system uses the tilt angle information and weight information to define the sitting posture. Moreover the system proposed in [20] is based to the weight information and the curvature spine information in order to define the sitting postures. The complementarity aspect of the sensing collected information 
defining systems using a variety of collected information is an open issue to study in future works.

The security of collected information and the privacy of person's information remain a challenge for the posture monitoring systems as this systems collect physiological and personal information. The systems must ensure the person privacy and respect the ethical and moral aspect. Moreover the feedback systems are studied in literature [24] because of their importance to lead the users to correct their posture. In fact the biological feedback is an open issue to develop in the future work

\section{CONCLUSION}

This paper is an overview about the existing posture monitoring systems. We studied the different aspect and architecture of the sitting posture monitoring systems with a deep analyze of the sensing information provided for defining the person's posture. These information have a key role on the identification of the human postures, the detection of the bad ones and the feedback system decision.

In the future work, we will design and propose a sitting posture monitoring system satisfying the most important aspect as the portability, easy of use, real time reaction and the best posture accuracy.

\section{REFERENCES}

[1] OLGA KHAZAN, "What Texting Does to the Spine," The Atlantic, November 2014

[2] American Academy of Orthopedic Surgeons, "Kyphosis (Roundback) of the Spine“, August 2016.

[3] Supriya Sathyanarayana, Ravi Kumar Satzoda, Suchitra Sathyanarayana, Srikanthan Thambipillai, "Vision-based patient monitoring: A comprehensive review of algorithms and technologies," Journal of Ambient Intelligence and Humanized Computing, pp. 225251, November 2015.

[4] Damien Brulin, Yannick Benezeth, Estelle Courtial, "Posture Recognition Based on Fuzzy Logic for Home Monitoring of the Elderly," IEEE Transactions on Information Technology in Biomedicine, pp. 974 - 982, July 2012

[5] Obdrzlek S1, Kurillo G, Ofli F, Bajcsy R, Seto E, Jimison H, Pavel M., "Accuracy and robustness of Kinect pose estimation in the context of coaching of elderly population," International Conference of the IEEE Engineering in Medicine and Biology Society, pp. 11881193, September 2012.

[6] Taieb-Maimon M1, Cwikel J, Shapira B, Orenstein I, "The effectiveness of a training method using self-modeling webcam photos for reducing musculoskeletal risk among office workers using computers," j.apergo, 2011.

[7] Dong-Jun Shin, Min-Sang Kim, Wook Song, Se Dong Min, Min Hong, "Implementation of Sitting Posture Monitoring System with Kinect," International Conference on Multimedia and Ubiquitous Engineering, pp. 144-150, May 2017.

[8] Kendall Ho, Christopher Yao, Helen Novak Lauscher, "Part2: Health apps, wearable, and sensors: The advancing fraintier of digital health,“ BC medical Journal, pp. 503-506, December 2017.

[9] Roh J, Park HJ, Lee KJ, Hyeong J, Kim S, Lee B., "Sitting Posture Monitoring System Based on a Low-Cost Load Cell Using Machine Learning," Sensors (Basel). 2018.

[10] Jingyuan Cheng, Bo Zhou, Mathias Sundholm, Paul Lukowicz, "Smart chair: What can simple pressure sensors under the chairs legs tell us about user activity?," IARIA XPS Press, 2013.

[11] Jullia Birsan, Diana Stavarache, Maria-Iuliana Dascalu, Alin Moldoveanu, "SpiMO - Sitting Posture Monitoring System," RiCHI 2017 Proceedings, 2017.
[12] E.Hedberg, J.Norn, M.Norrlf, S.Gunnarsson, "Industrial Robot Tool Position Estimation using Inertial Measurements in a Complementary Filter and an EKF," IFAC (International Federation of Automatic Control) Hosting by Elsevier Ltd, pp. 12748-12752, July 2017.

[13] A. Linkel, K. Daunoraviciene, J. Griskevisius, J. Ziziene, A. Juocevicius, I. Raudonyte, "Applications of inertial sensors in medicine: towards model-based rehabilitation of stroke, " IFAC (International Federation of Automatic Control) Hosting by Elsevier Ltd, pp. 442-447, 2015.

[14] Paul D. Groves, "Navigation using inertial sensors," IEEE Aerospace and Electronic Systems Magazine, pp. 42 - 69, April 2015.

[15] Wai Yin Wong, Man Sang Wong, "Trunk posture monitoring with inertial sensors," Eur Spine J, 2008.

[16] Q. Wang, W. Chen, A.A.A. Timmermans, C. Karachristos, J.B. Martens, P. Markopoulos, "Smart Rehabilitation Garment for posture monitoring," 37th Annual International Conference of the IEEE Engineering in Medicine and Biology Society (EMBC), 2015.

[17] Maheswaran Shanmugam, Sunilvignesh Nehru, Sathesh Shanmugam, "A wearable embedded device for chronic low back patients to track lumbar spine position," Biomed Res 2018 Special Issue, 2018.

[18] Anindya Nag, Subhas Chandra Mukhopadhyay, Jrgen Kosel, "Wearable Flexible Sensors: A Review,“ IEEE Sensors Journal, pp. 3949 - 3960 , May 2017.

[19] Giovanni Saggioab, Giancarlo Orengo, "Flex sensor characterization against shape and curvature changes," Sensors and Actuators A Physical, pp. 221-231, April 2018

[20] Manju Gopinath, Angeline Kirubha, "Real Time Monitoring of Posture to Improve Ergonomics," Journal of Biomedical Engineering and Medical Imaging, 2015.

[21] Sardini, auro Serpelloni and Viviane Pasqui, "Wireless-wearable T-shirt for posture monitoring during rehabilitation exercises," IEEE Transactions on Instrumentation and Measurement, pp. 439-448, 2015.

[22] L.E. Dunne, P. Walsh, B. Smyth, and B. Caulfield, "A System for Wearable Monitoring of Seated Posture in Computer Users," 4th International Workshop on Wearable and Implantable Body Sensor Networks (BSN 2007), pp 203-207, 2007.

[23] Harsh Gupta, "Smartphone Based Cervical Spine Stress Prevention," Smartphone Based Cervical Spine Stress Prevention. Journal of Software Engineering and Applications , pp 110-120, 2018.

[24] Da-Yin Liao, "Collaborative, Social-networked Posture Training (CSPT) through Head-and-Neck Posture Monitoring and Biofeedbacks," 19th International Conference on Enterprise Information Systems (ICEIS 2017), pp 158-165, 2017

[25] Azin Fathi, Kevin Curran, "Detection of spine curvature using wireless sensors," Journal of King Saud University Science, pp. 553560, 2017.

[26] Bilal El-Sayed, Noura Farra, Nadine Moacdieh, Hazem Hajj, Rachid Haidar, Ziad Haij, "A novel mobile wireless sensing system for realtime monitoring of posture and spine stress," 1st Middle East Conference Biomedical Engineering (MECBME), 2011. 
TABLE I

POSTURE MONITORING SYSTEMS ARCHITECTURE

\begin{tabular}{|c|c|c|c|c|c|c|}
\hline Papers & Sensor Type & $\begin{array}{l}\text { Information provided by } \\
\text { sensors }\end{array}$ & $\begin{array}{l}\text { Number } \\
\text { of } \\
\text { sensors }\end{array}$ & Sensors placement & $\begin{array}{l}\text { Communication } \\
\text { technology }\end{array}$ & Battery Performance \\
\hline $\begin{array}{l}\text { Jingyuan Cheng } \\
\text { et all.2013 [10] }\end{array}$ & Pressure sensors & $\begin{array}{l}\text { The total weight and the } \\
\text { distribution of weight and } \\
\text { force exercised to the four } \\
\text { legs }\end{array}$ & 4 & Under chair legs & $\begin{array}{l}\text { A } 2.4 \mathrm{GHz} \text { Zig- } \\
\text { bee module for } \\
\text { data transfer }\end{array}$ & $\begin{array}{l}5500 \mathrm{mAh} \text { battery with } \\
36 \text { hours autonomy }\end{array}$ \\
\hline $\begin{array}{l}\text { Roh J et all.2018 } \\
{[9]}\end{array}$ & Load sensors & Body weight ratio & 4 & Mounted on the seat plate & $\begin{array}{l}1 \mathrm{~Hz} \text { frequency } \\
\text { via the Arduino } \\
\text { board }\end{array}$ & NA \\
\hline $\begin{array}{l}\text { Jullia Birsan et } \\
\text { all.2017 [11] }\end{array}$ & Pressure sensors & Weight distribution & 11 & $\begin{array}{l}9 \text { pressure sensors on the } \\
\text { pillow and } 2 \text { pressure sen- } \\
\text { sors on the back }\end{array}$ & Bluetooth & $\overline{\mathrm{NA}}$ \\
\hline $\begin{array}{ll}\text { Bilal } & \text { El- } \\
\text { Sayed.2011 } & \\
{[26]} & \end{array}$ & $\begin{array}{l}\text { Inclinometer } \\
\text { Sensor and load } \\
\text { sensors }\end{array}$ & Posture angle and weight & 3 & $\begin{array}{l}\text { The inclinometer sensor po- } \\
\text { sitioned at the neck }+ \text { load } \\
\text { sensors placed on the feet } \\
\text { soles }\end{array}$ & $\begin{array}{l}\text { Wi-Fi data acqui- } \\
\text { sition device }\end{array}$ & $\begin{array}{l}\text { the battery used to } \\
\text { power the sensors and } \\
\text { DAQ module. }\end{array}$ \\
\hline $\begin{array}{l}\text { Wai Yin Wong et } \\
\text { all.2008 [15] }\end{array}$ & $\begin{array}{l}\text { Inertial sensors: } 1 \\
\text { 3D accelerometer } \\
\text { and } 3 \text { gyroscopes }\end{array}$ & $\begin{array}{l}\text { Tilting angles and trunk } \\
\text { angles of the thoracic and } \\
\text { lumbar regions }\end{array}$ & 3 & $\begin{array}{l}\text { Sensors embedded on the } \\
\text { garment on the upper and } \\
\text { trunk and in the pelvic level }\end{array}$ & $\overline{\mathrm{NA}}$ & $\begin{array}{l}4 \text { AAA size recharge- } \\
\text { able batteries (Ni-MH } \\
\text { type, } 1,100 \mathrm{mAh}, 1.2 \mathrm{~V}) \\
\text { for operational } 8 \text { hours. }\end{array}$ \\
\hline $\begin{array}{lc}\text { Q. Wang } & \text { et } \\
\text { all.2015 [16] } & \end{array}$ & Inertial sensors & Thoracic angle & 2 & $\begin{array}{l}\text { Vertebrae } \mathrm{T} 1 \text { and } \mathrm{T} 5 \text { of } \\
\text { spine }\end{array}$ & Bluetooth & $\overline{\mathrm{NA}}$ \\
\hline $\begin{array}{l}\text { Azin Fathi, Kevin } \\
\text { Curran.2017 [25] }\end{array}$ & $\begin{array}{l}\text { Inertial unit: ac- } \\
\text { celerometer and } \\
\text { gyroscope }\end{array}$ & $\begin{array}{l}\text { Acceleration and angles } \\
\text { change rate }\end{array}$ & 3 & $\begin{array}{l}\text { Cervical spine, } \text { thoracic } \\
\text { spine and lower lumbar } \\
\text { spine. }\end{array}$ & NA & $\begin{array}{l}\text { The shimmer sensor bat- } \\
\text { tery life is not to be } \\
\text { recharged for running } \\
\text { days. }\end{array}$ \\
\hline $\begin{array}{l}\text { Maheswaran } \\
\text { Shanmugam } \\
\text { all.2018[17] }\end{array}$ & $\begin{array}{l}\text { Gyroscope and } \\
\text { accelerometer }\end{array}$ & $\begin{array}{l}\text { Acceleration angle con- } \\
\text { verted to the bend angle }\end{array}$ & 1 & $\begin{array}{l}\text { The sensor unit is placed on } \\
\text { the lower back or at the shirt } \\
\text { pocket. }\end{array}$ & Bluetooth & NA \\
\hline $\begin{array}{l}\text { Da-Yin } \\
\text { Liao.2017 [24] }\end{array}$ & Accelerometer & Tilt angle & 1 & Earhook device & NA & NA \\
\hline $\begin{array}{l}\text { Harsh } \\
\text { Gupta.2018 } \\
{[23]}\end{array}$ & Accelerometer & Tilt angle & 1 & Smartphone accelerometer & NA & NA \\
\hline $\begin{array}{l}\text { Manju Gopinath } \\
\text { and Angeline } \\
\text { Kirubha.2015 } \\
{[20]}\end{array}$ & $\begin{array}{l}\text { Flex sensor and } \\
\text { cell load }\end{array}$ & $\begin{array}{l}\text { Voltage value caused by } \\
\text { resistance variation during } \\
\text { spine bending and body } \\
\text { load }\end{array}$ & 2 & $\begin{array}{l}\text { The Flex sensor placed on } \\
\text { the mid-thoracic region and } \\
\text { the load cell is placed be- } \\
\text { tween platforms on which } \\
\text { the subject can stand }\end{array}$ & NA & NA \\
\hline $\begin{array}{l}\text { Emilio Sardini et } \\
\text { all.2015 [21] }\end{array}$ & Inductive sensor & Inductance value & 1 & $\begin{array}{l}\text { sticked to the T-shirt } \\
\text { throughout the patient back } \\
\text { and chest }\end{array}$ & Bluetooth & $\begin{array}{l}9 \mathrm{~V} \text { batteries and about } \\
1200 \mathrm{mAh} \text { allowing con- } \\
\text { tinuous functioning of a } \\
\text { few hours }\end{array}$ \\
\hline $\begin{array}{l}\text { L.E. Dunne et } \\
\text { all.2007 [22] }\end{array}$ & $\begin{array}{ll}\text { Plastic } & \text { optical } \\
\text { fiber } & \text { (POF) } \\
\text { sensor } & \end{array}$ & Bend degree & 1 & $\begin{array}{l}\text { Plastic optical fiber (POF) } \\
\text { integrated to the garment. A } \\
\text { light source and light sen- } \\
\text { sors are placed at the edges } \\
\text { of the POF. The POF is } \\
\text { stuck to the subject back }\end{array}$ & Bluetooth & NA \\
\hline
\end{tabular}


TABLE II

POSTURE MONITORING SYSTEMS ACCURACY

\begin{tabular}{|c|c|c|c|c|}
\hline Papers & Posture Accuracy Evaluation & Test Scenarios & Subjects Criteria & Number of Postures \\
\hline $\begin{array}{l}\text { Jingyuan Cheng et } \\
\text { all.2013 [10] }\end{array}$ & $\begin{array}{l}\text { Accuracy of the posture classifica- } \\
\text { tion: } \\
-82.6 \% \text { for the experimental tests } \\
-78.3 \% \text { for the daily activities }\end{array}$ & $\begin{array}{l}\text { - Experimental tests: the } \\
\text { subject seated in the chair } \\
\text { repeat } 12 \text { postures and ac- } \\
\text { tions } 20 \text { times. } \\
\text { - Tracking daily activities: } \\
\text { the subject is asked to sit } \\
\text { for at least } 8 \text { hours during } \\
3 \text { days and perform nor- } \\
\text { mal work routine. }\end{array}$ & $\begin{array}{l}5 \text { healthy subjects: } 1 \text { fe- } \\
\text { male, } 4 \text { males, aged be- } \\
\text { tween } 23 \text { and } 34 \text { years. }\end{array}$ & 7 sitting postures \\
\hline Roh J et all.2018 [9] & $\begin{array}{l}\text { The average of posture classifica- } \\
\text { tion rate: } 97,2 \% \text {. }\end{array}$ & $\begin{array}{l}2 \text { tests evaluation: } \\
\text { - Preliminary tests: } \\
\text { posture changing with } \\
\text { instruction. } \\
\text { - Main tests: posture } \\
\text { changing randomly. }\end{array}$ & $\begin{array}{l}24 \text { healthy adult males }(15 \\
\text { in the preliminary tests } \\
\text { and } 9 \text { in the main tests): } \\
\text { age: } 27.6 \pm 5.6 \text { years, } \\
\text { height: } 174.5 \pm 6.2 \mathrm{~cm} \text {, } \\
\text { and body weight: } 71.9 \pm \\
8.7 \mathrm{~kg}\end{array}$ & 6 sitting postures \\
\hline $\begin{array}{l}\text { Jullia Birsan et all.2017 } \\
{[11]}\end{array}$ & $\begin{array}{l}\text { Users satisfaction: } 65 \% \text { of partic- } \\
\text { ipants consider the system is effi- } \\
\text { cient to improve lifestyle }\end{array}$ & Tracking sitting posture & $\begin{array}{l}8 \text { subjects: } 4 \text { males and } 4 \\
\text { females, age } 20-50\end{array}$ & NA \\
\hline Bilal El-Sayed.2011 [26] & NA & $\begin{array}{l}\text { Sitting posture scenario: } \\
\text { Beginning with a correct } \\
\text { posture, then bent over, } \\
\text { then straightened up for } \\
\text { short time, then going } \\
\text { through a period of fluc- } \\
\text { tuation. }\end{array}$ & $\overline{\mathrm{NA}}$ & 3 sitting postures \\
\hline $\begin{array}{l}\text { Wai Yin Wong et all.2008 } \\
{[15]}\end{array}$ & $\begin{array}{l}\text { The averaged root mean squared } \\
\text { differences between the measure- } \\
\text { ments of the system and the ref- } \\
\text { erence system: } \leq 1.5^{\circ} \text { for dy- } \\
\text { namic measurement, }<3.1^{\circ} \text { for } \\
\text { the sagittal plane and } \leq 2.1^{\circ} \text { for } \\
\text { the coronal plane }\end{array}$ & $\begin{array}{l}\text { Track the posture during } \\
\text { daily activities }\end{array}$ & $\begin{array}{l}4 \text { females and } 5 \text { males: } \\
\text { age: } 25.2 \pm 4.8 \text { years, } \\
\text { weight: } 50.5 \pm 7.2 \mathrm{~kg} \text {, } \\
\text { height: } 1.7 \pm 0.09 \mathrm{~m} \text { and } \\
\text { BMI: } 18.4 \pm 1.1 \mathrm{~kg} \mathrm{~m}^{-2}\end{array}$ & NA \\
\hline Q. Wang et all.2015 [16] & $\begin{array}{l}\text { Root mean squared error of the } \\
\text { thoracic angle compared to the } \\
\text { commercial optical tracker (PST- } \\
55 / 110 \text { series): } 3.57\end{array}$ & $\begin{array}{l}\text { Stand straight to cali- } \\
\text { brate the system. Then } \\
\text { bend forward different an- } \\
\text { gles: } 15^{\circ}, 30^{\circ}, 45^{\circ}, 60^{\circ} \\
\text { and } 75^{\circ} \text { randomly. This } \\
\text { exercise is repeated three } \\
\text { times. }\end{array}$ & $\begin{array}{l}7 \text { subjects: } 4 \text { females and } \\
3 \text { males }\end{array}$ & NA \\
\hline $\begin{array}{l}\text { Azin Fathi, Kevin Cur- } \\
\text { ran.2017 [25] }\end{array}$ & $\begin{array}{l}\text { Classification accuracy according } \\
\text { to the training data (the num- } \\
\text { ber of system training to distin- } \\
\text { guish between two incorrect pos- } \\
\text { ture (Hunch Back and Slouch } \\
\text { Back) using prerecorded data) : } \\
\text { accuracy } 85 \% \text { (1 Training data), } \\
95 \% \text { (5 Training data), 100\% (20 } \\
\text { Training data) }\end{array}$ & $\begin{array}{l}10 \text { tests of hunched back } \\
\text { and } 10 \text { tests of slouched } \\
\text { back }\end{array}$ & $\begin{array}{l}5 \text { subjects: } 2 \text { males and } 3 \\
\text { females aged between } 25 \\
\text { and } 60\end{array}$ & 2 sitting postures \\
\hline $\begin{array}{l}\text { Maheswaran Shanmugam } \\
\text { et all.2018 [17] }\end{array}$ & $\begin{array}{l}\text { Accuracy of bad posture recogni- } \\
\text { tion: } 95 \%\end{array}$ & $\begin{array}{l}\text { Begin with straight pos- } \\
\text { ture then posture change } \\
\text { over time. }\end{array}$ & 10 subjects & NA \\
\hline Da-Yin Liao.2017 [24] & NA & $\begin{array}{l}\text { The teenagers are asked to } \\
\text { wear the training headset } \\
\text { for at least sixty minutes } \\
\text { a day during } 10 \text { days }\end{array}$ & 6 teenagers & NA \\
\hline Harsh Gupta.2018 [23] & NA & $\begin{array}{l}\text { The subject is asked to } \\
\text { keep the application work- } \\
\text { ing for as long as he use } \\
\text { his smartphone during a } \\
\text { week }\end{array}$ & 100 people of ages $10-60$ & NA \\
\hline $\begin{array}{l}\text { Manju Gopinath and An- } \\
\text { geline Kirubha.2015 [20] }\end{array}$ & NA & $\begin{array}{l}\text { Posture variation: bending } \\
\text { the spine to mimic poor } \\
\text { posture }\end{array}$ & 3 subjects & NA \\
\hline $\begin{array}{l}\text { Emilio Sardini et all.2015 } \\
\text { [21] }\end{array}$ & $\begin{array}{l}\text { Uncertainty of lengthening values: } \\
4.9 \mathrm{~mm}\end{array}$ & $\begin{array}{l}\text { The subject is sitting and } \\
\text { slowly performs lengthen- } \\
\text { ing and straightening of } \\
\text { the body. }\end{array}$ & $\begin{array}{l}4 \text { subjects: mean age } 25.6 \\
\text { years, mean height } 178 \mathrm{~cm}\end{array}$ & NA \\
\hline $\begin{array}{l}\text { L.E. Dunne et all.2007 } \\
\text { [22] }\end{array}$ & $\begin{array}{l}\text { A mean value error of spinal bend } \\
\text { degree: } 0.64 \text { degrees } \\
\text { A mean time error: } 0.53 \text { seconds }\end{array}$ & $\begin{array}{l}\text { The subject changes his } \\
\text { bend degree over time. }\end{array}$ & 9 healthy subjects. & NA \\
\hline
\end{tabular}

